\title{
Frontiers
}

\section{in the Psychotherapy} of Trauma \& Dissociation

The Memory Wars in England: A Personal and Professional Experience Valerie Sinason, PhD

The Official Clinical Journal of the International Society for the Study of Trauma and Dissociation 


\section{Frontiers in the Psychotherapy of Trauma \& Dissociation}

The Official Clinical Journal of the ISSTD

\section{EDITOR}

ANDREAS LADDIS, MD, Private Practice and Faculty, Boston University, School of Public Health, Boston, Massachusetts, USA

\section{ASSOCIATE EDITOR}

MARTIN J DORAHY, PhD, Professor, Department of Psychology, University of Canterbury, Christchurch, New Zealand and The Cannan Institute, Brisbane, Australia

Frontiers in the Psychotherapy of Trauma \& Dissociation is published by the International Society for the Study of Trauma and Dissociation, Inc., 1420 New York Ave NW, Fifth Floor, Washington, DC 20005.

\section{Annual Subscription, Volume 3, 2019}

Online subscription is part of the membership dues of the International Society for the Study of Trauma and Dissociation. Visit http://www.isst-d.org/default.asp?contentID=44.

Production and Advertising Office: ISSTD Headquarters, 1420 New York Ave NW, Fifth Floor, Washington, DC 20005.

Copyright @2019 International Society for the Study of Trauma and Dissociation. All rights reserved. No part of this publication may be reproduced, stored, transmitted, or disseminated in any for or by any means without prior written permission from the International Society for the Study of Trauma and Dissociation. The publisher assumes no responsibility for any statements of fact or opinion expressed in the published papers. The appearance of advertising in this journal does not constitute an endorsement or approval by the publisher, the editor, the editorial board, or the board of directors of the International Society for the Study of Trauma and Dissociation of the quality or value of the product advertised or of the claims made of it by its manufacturer.

Subscriptions to this journal are acquired through membership in the International Society for the Study of Trauma and Dissociation only.

Visit http:/ / www.isst-d.org/default.asp?contentID=45.

Permissions. For further information, please write to info@isst-d.org.

\section{EDITORIAL BOARD}

ELIZABETH S BOWMAN, MD, Editor Emerita, Journal of Trauma \& Dissociation, Adjunct Professor of Neurology, Indiana University School of Medicine, Indianapolis, Indiana, USA

LAURA S. BROWN, PhD, Private Practice, Seattle, Washington, USA

RICHARD A CHEFETZ, MD, Private Practice, Faculty and Founding Member Institute of Contemporary Psychotherapy \& Psychoanalysis, Distinguished Visiting Lecturer: William Alanson White Institute of Psychiatry, Psychoanalysis \& Psychology, New York City, USA

CONSTANCE J DALENBERG, PhD, Trauma Research Institute, California School of Professional Psychology, San Diego, California, USA

J.K. JUDITH DANIELS, PhD, Faculty of Behavioural and Social Sciences, University of Groningen, The Netherlands

STEVEN N GOLD, PhD, Professor, Center for Psychological Studies, and Founding Director, Trauma Resolution \& Integration Program, Nova Southeastern University, Fort Lauderdale, Florida, USA ELIZABETH B HEGEMAN, PhD, Professor, Department of Anthropology, John Jay College of Criminal Justice, New York, New York, USA 
RICHARD P. KLUFT, MD, PhD Private Practice and Clinical Professor of Psychiatry, Temple University School of Medicine; Faculty Member, Philadelphia Center for Psychoanalysis,

Philadelphia, Pennsylvania, USA

CHRISTA KRÜGER, MD, Professor of Psychiatry, University of Pretoria, Pretoria, Gauteng, South Africa

KARLEN LYONS-RUTH, PhD, Professor of Psychology, Harvard Medical School, Cambridge, Massachusetts, USA

ALFONSO MARTÍNEZ-TABOAS, PhD, Professor, Albizu University, San Juan, Puerto Rico

WARWICK MIDDLETON, MD, Adjunct Professor, Cannan Institute, Brisbane, Australia ELLERT

R. S. NœENHUIS, PhD, Department of Psychiatry and Outpatient Department Mental Health Care Drenthe, Assen, The Netherlands

SANDRA PAULSEN, PhD, Bainbridge Institute for Integrative Psychology, Bainbridge Island, Washington, USA

VEDAT SAR, MD, Professor of Psychiatry, Koç University School of Medicine (KUSOM), Istanbul, Turkey

JOYANNA SILBERG, PhD, Trauma Disorders Program, Sheppard Pratt Health Systems, Baltimore, Maryland, USA

ELI SOMER, PhD, Professor, School of Social Work, University of Haifa, Israel

KATHY STEELE, MN, CS, Private Practice, Atlanta, Georgia, USA

ONNO VAN DER HART, PhD Emeritus Professor of Psychopathology of Chronic Traumatization, Department of Clinical and Health Psychology, Utrecht University, Utrecht, The Netherlands VICTOR WELZANT, PsyD, Sheppard Pratt Health Systems, Trauma Disorders Program

\section{REVIEWERS}

JOHN BRIERE, PhD, Associate Professor of Psychiatry and Psychology, University of Southern California Keck School of Medicine, Los Angeles, California, USA

SHELDON IZKOWITZ, PhD, Clinical Associate Professor of Psychology and Clinical Consultant, Postdoctoral Program, New York University, New York City, USA and Teaching Faculty \& Supervisor of Psychotherapy and Psychoanalysis, National Institute for Psychotherapies, New York City, USA

MARY-ANNE KATE, PhD Researcher at University of New England, Australia; University of New England, New South Wales, Australia

ULRICH F. LANIUS, PhD, Private Practice, West Vancouver, British Columbia, Canada

\section{SUPPORTERS}

ISSTD thanks its generous supporters whose contributions have made this publication possible:

Andreas Laddis, MD, USA

\section{The \\ Cannan \\ Institute}

Cannan Institute, Australia Warwick

Middleton, MD, Australia

Dana Ross, MD, Canada

Martin J. Dorahy, PhD, New Zealand

Kate McMaugh, Australia

Sara Y. Krakauer, USA 


\title{
ARTICLE \\ THE MEMORY WARS IN ENGLAND: A PERSONAL AND PROFESSIONAL EXPERIENCE
}

\author{
VALERIE SINASON \\ Founder and Former Director, Clinic for Dissociative Studies; President, Institute for Psychotherapy \\ and Disability; ESTD newsletter editorial team; ISSTD Board Member
}

The term "false memory syndrome" originated in America in 1992 and spread to the UK in 1993. In the context of the success of the women's movement in focusing on domestic abuse and then child abuse, the term was seductively softer than calling a victim a liar. Working with abuse survivors in the U.K. at that time, the author witnessed the process whereby, if this scientifically non-existent syndrome was to be publicly accepted, then the anger had to be directed elsewhere. It went, via the media, who are not held back by professional codes in the way a clinician is, to the professionals, especially psychotherapists, who had heard the allegation and therefore must have caused it. The author shows how the success of this anti-professional campaign, aided and abetted by disinformation and denial, affected work with abuse survivors ever since then. Psychoanalysts and psychotherapists who had previously worked in confidential privacy now found their work was being attacked and clinicians working in public service were subject to all kinds of reporting procedures if the allegations involved children. The author describes her own experiences of this. A paradigm shift led to both greater transparency and awareness of trauma but also more directives over treatment protocols. The author was working in the National Health Service (NHS) as a Consultant Psychotherapist when these attacks began. Although her work in revealing the level of sexual abuse experienced by children and adults with an intellectual disability was praised, the moment she reported from a piece of clinical work that involved allegations of ritual

Author Contact Information: E-mail: VSinason@aol.com. 
abuse, personal media attacks began that have continued ever since. The author warns that whenever society declares that a particular kind of abuse is never possible (as it sounds so bizarre), paedophiles are the only ones who benefit.

KEYWORDS false memory in the UK, psychoanalysis and reality

\section{INTRODUCTION}

From the 1960s to the 1990s onwards in the USA and UK, there was a growth of understanding of human rights with the development of the Women's Movement and an awareness of women's and children's rights. A pediatrician, Dr. C. Henry Kempe (Kempe, 1962), coined the term "battered child" and was the first to name child abuse and neglect showing how the term "clumsiness" could disguise the reality of physical abuse. The first Rape Crisis center in the United Kingdom (UK) opened in 1973, and The Convention on the Elimination of all Forms of Discrimination Against Women (CEDAW) was adopted by the United Nations (UN) General Assembly in 1979. With transatlantic awareness growing of the impact of domestic and child abuse, a backlash was inevitable. Unlike other areas of inequality and damage (homelessness, racism, lack of access to services), rape was unequivocally a crime and therefore involved forensic attention. Providing adequate, consistent details to aid police in their enquiries highlighted the complex relationship between memory and trauma. Without adequate physical evidence and, often, abuse being a crime with no witnesses except the perpetrator and the victim, a greater valuation was placed on memory.

In Philadelphia an American man, Peter Freud, had an impact on transatlantic views on memory and disclosure of sexual crimes by coining the term "False Memory Syndrome" in 1992 (McHugh, 2008, pp. 66-67). Dr. Ralph Underwager, his wife Hollida Wakefield, and Peter and Pamela Freyd founded the False Memory Society Foundation (FMSF) after the Freyds' daughter recalled Peter Freyd abusing her as a child. Describing the FMSF as a "ray of light" (Sinason, 1998), a British father, Roger Scotford, launched a UK society, the False Memory Society (FMS) in 1993 after he was accused of incest. Very importantly, with both the Freyds and Scotford, and many others, private discussion of abuse by grown-up daughters was turned into public discourse by allegedly innocent parents.

Adults who told their parents privately of childhood abuse memories were and are still being publicly named, shamed and identified, despite a temporary lull. Additionally, it was mainly adult daughters in their 20s who were being publicly named by their fathers. The term "false memory syndrome" was not applied to offenders (largely male) who were genuinely dissociative of the crimes they had committed which were corroborated. 
Rather, it was applied to adults (mainly women) who recalled their parent/s sexually abusing them as children. Although both the FMSF and the FMS publicly accepted that child abuse was a serious problem, their focus primarily was on adults. Indeed, there was an ambiguous attitude to incest with children with Underwager declaring that sex with children could be seen as part of "God's will" (Sinason, 1998). The media success of the FMSF and the FMS meant that even revelations such as Underwager's views (and eventual resignation) did not affect their strength. Additionally, they succeeded in naming a new enemy: psychotherapy. It was said that many of those alleging childhood abuse recovered the memories in therapy.

Struggling with the ethics of private communications versus social involvement, the psychotherapy professions largely surrendered through inactivity, fearfulness and ethical confusion, and the "war" was largely a successful attack by the FMS. Children, whose testimonies were less valued in the UK at that time, and less likely to make disclosures that would lead to court involvement, did not receive the same level of public attack. Some professionals, fearful of being seen as "polarized" found themselves unprofessionally responding to litigious family members and forgetting who their client was. Registering bodies accepted unscientific views on the dangers of memory.

This paper looks at the so-called "Memory Wars" from the impact of personal and professional experience of clinical attack from the FMS and related groups. To understand the context leading to it also means appraising attitudes to abuse in general and the concepts of neutrality, ethics and external reality within my professions of psychoanalysis and psychoanalytic psychotherapy leading up to it.

\section{THE BRITISH CONTEXT}

\section{Abuse, Psychoanalysis and External Reality}

In the UK, psychoanalysts and child psychotherapists have until recently been rarely involved in public political issues. Rather, they tended to become absorbed in debate and disagreements more "locally," often within different schools of psychoanalytic thought. Indeed, in choosing a profession that privileges privacy and confidentiality, it was concerning for an analyst to be politically noticeable or indeed to be an author outside of small psychoanalytic or academic publishers. Having a name that could be recognized outside of a small clinical area carried with it a concern that patients would lose a neutral home. Indeed, D. W. Winnicott was one of the few major early British psychoanalysts who wrote regular articles on parenting and from 1943-1962 made over 50 broadcasts for the BBC (Ades, 2016; Kahr, 2016).

Psychoanalysis and psychoanalytic psychotherapy, even when practiced in the National Health Service rather than privately, have always 
been concerned with confidentiality. Even before the increasing statutory demands for cyberprotection, encryption, locked filing cabinets, verbal consent, disguise in clinical writing, psychoanalysts and psychoanalytic psychotherapists took care. There was widespread concern at anything that could breach the privacy of therapist and patient, including when the patient was also a therapist or analyst. Indeed, whilst a trainee child psychoanalytic psychotherapist at the Tavistock Clinic in London, the largest National Health Service psychoanalytic training and treatment center in the UK, I found problems in creating a House Journal for staff. The Tavistock Gazette, which was finally launched in 1984, evoked significant anxiety in potential contributors. The most common concern was either, "But supposing my analyst sees what I have written" or "supposing my patient sees what I have written." At the same time there was an urban myth that a child psychotherapist nearly drowned from swimming underwater after seeing a patient of hers at the local swimming pool! The first shows I created for the Tavistock on its 25th anniversary, at the request of the then Chair, Dr. Alexis Brook, necessitated senior psychoanalysts and psychoanalytic psychotherapists playing leading roles to show that it was permissible for juniors to join in.

The fear of damaging the frame by being seen outside the consulting room was embedded in some of my own responses at the time. On one occasion in the 1980s, I was at Heathrow Airport with my husband and daughter to meet my son. To my surprise, a patient with a severe intellectual disability was there with her foster mother. I whispered the warning word, "patient," and my well-trained family disappeared whilst I said hello. The next day in the consulting room the patient said, "Why you not introduce me to your man and your girl? You ashamed of me?" I apologized and said it would not happen again, but I had worried it would be an intrusion for her. Such behavior would not be repeated as I slowly learned the transparency and relational attachment approach needed for extreme trauma.

Perhaps the mood of the time can be reflected by the ethical stance of Anne Hayman, a British independent group psychoanalyst, who in the 1960s was willing to face going to prison rather than revealing whether someone had been her analysand or not. Forty years later (Hayman, 2003, 2013) she was able to clarify her thinking of the time. She was not trying to protect the identity of a specific patient, but, far more seriously, protect psychoanalysis. She explained to the court that even if the alleged patient gave her permission to speak, it could not be called informed consent. She considered that the nature of the transference and unconscious processes meant that informed consent did not exist. Unlike the legal allowance given to priests at that period to keep confidentiality, there was none given to psychoanalysts. She had no legal right (then or now) to withhold information from the court. The judge excused her, understanding that she was 
acting on ethical principle. However, in the 40 years that have passed, Hayman is aware of more complex ethical issues that could appear in treatment and recommends discussion with a colleague if the patient represents a real danger that does not lessen through treatment, or if an analyst hears dangerous information about a colleague from a patient.

Hayman's attitude was very much echoed by analysts of the time. Indeed, Anne Marie Sandler (personal communication, 1997), a leading Contemporary Freudian psychoanalyst and former supervisor of mine, stated that if a patient told her they had committed a murder, she would have to keep that confidential. Within the boundary of the session, the subject on the couch was not a criminal or a victim, only an analysand. Society may judge the patient, but the analyst must stay with psychoanalytic complexity.

It can now be considered retrospectively that the shock at dealing with the power of the unconscious might have led to a foreclosure on the potential shock of external reality. Perhaps it was, therefore, unsurprisingly no surprise that the small number of British Psychoanalysts who were also child abuse and victim-perpetrator pioneers (like Professors Arnon Bentovim, Eileen Vizard, Judith Trowell, and Drs. Mervin Glasser, Estela Welldon, Brendan McCarthy and Robert Hale), worked in the National Health Service. At one level they could speak openly about the legal-political implications because their jobs required them to do so (Vizard, Monck, \& Misch, 1995), but they also took those jobs because it required such openness despite professional and public denial. However, a theoretical split between psychic reality and external reality was enacted by the divisions between complete confidentiality and limited confidentiality.

The first Rape Crisis centers began in 1972 in the UK (similar to the timing in the USA), and the impact of the film Sibyl added to societal concerns about abuse in the UK from 1976 (again similar to the timing in the USA). These events highlighted the profound split between the National Health Service, which was supposed to provide free access to healthcare for all, the voluntary sector, which largely consisted of charities and survivor professionals and carried the main burden of trauma work, and private psychoanalytic work. In this period, psychoanalytic practitioners' relationship with law was separated from my training and work. It was part of civic duty. Sexual abuse, memory and trauma were rarely mentioned in papers or in child or adult treatment.

It was the creation of Childline, a charity phoneline set up by Esther Rantzen in 1986, the Department of Health draft report on Working Together: A Guide to Arrangements for Inter-agency Cooperation for the Protection of Children (1986) and the Cleveland child abuse scandal with resulting inquiry in 1987 that affected child practitioners and the public more broadly. Judge Elizabeth Butler-Sloss was appointed to lead the latter Inquiry (1987), and whilst commenting that more sexual abuse of children existed than had 
been considered earlier, her report produced a split response with professionals, some of whom felt validated by the acceptance of large-scale child abuse and some of whom felt denigrated by the caveats. It has taken years to address this (Richardson \& Bacon, 2018). The public media focused on the idea that naïve professionals had over-valued children's testimony. Nevertheless, both government reports acknowledged the need to "believe" children whilst being aware not everything would be literally correct-a tension that has remained crucial for practice and treatment in the three decades since.

Nevertheless, the understanding that the reality of trauma necessarily evoked fears about memory solidified. Hurting a child was illegal, and disclosures suddenly entered the forensic field. Perpetrators, alleged perpetrators and their allies focused on memory research to disprove clinical findings on the impact of alleged trauma.

Three pivotal personal and professional moments in the late 1980s altered my internal and external position, and the timing was not coincidental.

\section{The First Moment of Change}

This was the personal and professional recognition that, unlike priests, psychoanalysts and child psychotherapists had no legal power to withhold information from courts. Although Anne Hayman was asked to provide clinical details in the 1960s, this was an extremely rare occurrence. Whilst psychologists, social workers and psychiatrists as statutory professions had more impingements on their confidentiality, psychoanalysts and psychoanalytic psychotherapists largely felt free from this. It is hard to convey the impact of that historic moment when child psychotherapists realized our adherence to confidentiality without external impingements did not come with our post. The growth of the role of social workers and other statutory professions made us recognize professional limitations. Psychic reality had been perceived as the key issue in treatment, and the new awareness of trauma reality was taking time to percolate. I was able to grasp this issue early as I worked mainly with children with an intellectual disability. The extra vulnerability of children and adults with an intellectual disability to the reality of abuse was becoming evident ahead of other specific clinical groups.

\section{The Second Moment of Change}

This was the first impact of transparency on a child I was working with.

Mary, aged 10, had a mild intellectual disability. She had disclosed sexual abuse by her father in her therapy sessions which took place in a National Health Service specialist children's residential unit. Social services, the 
child psychiatrist, school and psychotherapy all agreed on the extreme likelihood of abuse and were relieved she was in a residential placement. At that time, it was not felt that children with an intellectual disability made good witnesses. However, her father, perhaps sensing this, decided to take court action to remove her from the unit and bring her home to go to a local day school. This meant therapeutic confidentiality would be lost as the largest amount of description came from therapy sessions. I explained this to the child, dealt with her terror and rage, and prepared her for court. To our surprise, on seeing that all the professionals were willing to testify, the father decided to withdraw his case. With great relief I told this to the child. To my surprise she shouted at me "You coward, you pimp! You are frightened of my father like all of them and you will leave me at risk with him at holidays!"

Mary was tragically correct. The relief we felt that she was largely protected was because we were all frightened. Frightened of the truth of her abuse and the adversarial court experiences of the time. Frightened of the lack of professional support in dealing with reality trauma. On an easier level, it was a moment that allowed me to realize that telling children there were limits to confidentiality if they were in danger could have therapeutic benefits. As $80 \%$ of the children with intellectual disability I worked with turned out to be sexually abused, I learned to deal with my fears of reality. Additionally, in starting to work with adults with profound multiple disability I discovered for myself the awful ubiquity of abuse throughout the lifespan in this client group. I began writing about it in professional journals (Sinason, 1988a, 1988b, 1988c). Brendan McCarthy's paper (1988) on the hatred felt to survivors as messengers of abuse was helpful and, in joining the Tavistock Clinic Child Abuse workshop convened by psychiatrist and psychoanalyst Arnon Bentovim, I was privileged to join the key analytic colleagues working in this area. In 1988, a paper I wrote on the use of toys in working with abused children to my surprised received a "unanimous" rejection from the Journal of Child Psychotherapy. It was then published by the British Journal of Psychotherapy and received positive feedback. I later learned that the editorial board of the Journal of Child Psychotherapy had been split over how open to be.

It is astonishing to recall that as late as 1993, I was given sessions at the Anna Freud Clinic in London to implement child abuse guidelines. They had not been necessary in the profession previously. Outside of the analytic groups, external disability organizations welcomed a new colleague concerned about abuse of this extra vulnerable group.

Nevertheless, despite our shock at levels of sexual trauma, no issues around memory were raised outside of the careful psychoanalytic understanding that distortion and transformation could happen. 


\section{The Third Moment of Change for Me: The Department of Health Project}

The Children Act of 1989 tasked each local authority with the protection of children. Although there was still a very small interest in child victimperpetrators, there was awareness that all these children who were physically and sexually abused were hurt by adults, and largely by their parents. And what had led the parents to abuse them? A backlash showed itself through the familiar defenses of "shooting the messenger." It was not the children who were lying; it was bad therapists who had installed these ideas. The British environment was becoming ready for an alternative reason to manage the catastrophe of increasing numbers of people disclosing childhood sexual abuse. Allegedly innocent adults and adults whose abusive acts were proved in court were affected by the societal transformation, and as the UK entered the 1990s more changes began to happen. The growth of major survivor organizations such as Survivors Trust and NAPAC (National Association for People Abused in Childhood), and the influence of Simon's (1992) paper "Incest-see under Oedipus Complex," meant that psychoanalysis was under attack for not recognizing abuse by one group and under attack for recognizing it in fantasized form by another.

Whilst my papers and lectures on disability and abuse gained a largely thoughtful and positive response, everything was to change when the third factor entered my life.

\section{The Department of Health Project}

In 1989, as a respected professional in the field of disability, comfortable within the containment of a pioneering organization (The Tavistock Clinic) and my accrediting body (the Association of Child Psychotherapists), I was approached by a Swedish psychologist, Anders Svensson, for help with a woman with an intellectual disability who described a horrific level of torture (Sinason, 1994; Sinason \& Svensson, 1994). The counter-transference experience of being struck dumb through terror was different to anything I had previously encountered clinically (Sinason \& Svensson, 1994). Indeed, I was not able to discuss it with colleagues for a year, after which the Portman Clinic, the forensic arm of the Tavistock, provided consultation to Anders Svensson, a Scotland yard link for the Swedish police and a completely new turning for my work. It took time to realize that the extra countertransference terror I experienced came from my fear, unfiltered due to the almost complete lack of societal knowledge of this level of torture.

In speaking in Pitlochry in Scotland in 1990 about this piece of work as the final sentence in a talk on abuse, I was overwhelmed with requests from white professional middle-class and upper-class women who claimed they were victims of ritual abuse. They all spoke of inadequate police and therapeutic responses. They alleged major crimes committed by organized 
groups including oral, anal and vaginal abuse, necrophilia, abuse and murder of animals, enforced pregnancies and infanticide, murder and cannibalism as well as despoiling of graveyards, and eating non-food substances.

Confident in the research grounding I had received, and in my own awareness that this was something new for me to consider, I sought the help of a senior colleague at the Tavistock, a psychiatrist and psychoanalyst, Dr. Robert Hale. With the agreement of our different departments, we sought funding from the Department of Health (DOH) for a Pilot Study to investigate this cluster of allegations.

There were two central aims for this $\mathrm{DOH}$ project. Firstly, we wished to describe the clinical phenomena presented by children and adults showing indicators of trauma and alleging ritual abuse, and secondly, we aimed to draw on police assistance in attempting to confirm or otherwise the allegations of abuse in a small sample. Following my clinical and research trajectory in which the Tavistock taught us that new subjects should be examined carefully, I was naïve to the societal responses that would follow.

\section{The Beginning of False Memory}

From 1992 onwards, there was a negative media response to the Department of Health-funded project that my previous work on disability and abuse had never provoked or excited. The usually libertarian small weekly British paper Private Eye was a key player here, using headings like "Satanic Panic" together with mainstream papers. Suddenly in the public domain there was discussion in the media and radio about recovered memory and its dangers. In 1993 the British False Memory Society was formed and "satanic panic" was one of its first issues to attack. With extreme abuse, the False Memory Society as well as skeptical professionals and members of the public had found an area they could join forces on. Ironically, at the same time, novels and books on extreme abuse were extremely popular. A dissociative split was emerging in public culture.

We were part of this. The design of the Department of Health (DOH) pilot study was inevitably affected by the new growing pressure on the fallibility of memory, trauma memory and "recovered memory," especially. Although it had not been part of our thinking for the original project, we found it important to report that the existence of recovered memory was found in only two cases out of the overall sample $(n=51)$. In both cases the recovered memories of abuse co-existed with abuse memories that had never been forgotten. Initially, societally, evangelist religious beliefs were held responsible for allegations of ritual abuse. This connection was similarly found in only two out of 51 cases. In both these cases the subjects turned to evangelist groups after the alleged abuse because no one else would listen.

Enduring psychotic illness was not a significant feature in any of these cases. Nor had there been a previous diagnosis of Munchhausen's. In other 
words, there was not a mental disturbance of a kind that distorts a coherent narrative or prevents giving adequate testimony. Dissociative Identity Disorder (DID) was found in eight of the 18 initially interested in police liaison.

There was a wide range of evidence brought by the subjects to substantiate their accounts, including photographs, alleged ceremonial objects, medical and educational records, current injuries, and, even more worryingly, proof of unregistered children. The prestigious Radio 1 News Program, The Today Program, considered this significant enough to be its headline item.

In none of the cases was a subject wishing to pursue legal proceedings against an alleged abusing parent. In fact, therapy provided a context for some in which they felt able to reconnect with parents who had allegedly abused them in the past, even parents who were allegedly continuing to abuse them. Indeed, for two subjects who were reunited with their families during the project, the families themselves welcomed the approach and admitted significant elements of the past abuse.

There was an inherent flaw in the small part of the project that involved police liaison. We had identified and gained permission for an experienced officer to be a consistent part of the research team looking into each case. This permission was later rescinded at a higher level, and therefore, there was no consistent police presence. No case was investigated to our full satisfaction.

There were three participants who alleged punishment rapes for talking to the project. Medical examination confirmed the reality of rape, but the participants concerned did not want the investigation to go further. They felt they would be in even greater danger if they did this. As a result of the investigation, two cases were passed to the Crown Prosecution Service.

Where there was a custody dispute, it proved extremely difficult for the allegations of a non-custodial parent to be investigated de novo. Investigation was not deemed appropriate where ritual and sexual activity involved solely adult participants. However, this raised important issues concerning adult "vulnerable victims," including those with a learning disability. Some police who were not acquainted with DID failed to see how such patients could give reliable evidence.

The Clinic for Dissociative Studies in London (which I Founded and was Director of from 1998-2018) was created to provide a treatment setting for patients making such allegations who were left without treatment after the ending of the project. A major liaison was made with the Metropolitan Police. Detective Chief Inspector Clive Driscoll, who had a child protection and domestic violence background and knowledge, was given a half-day a month as a police liaison officer. In editing the first British clinical book on ritual abuse (Sinason, 1994), which was launched in the House of Lords 
as well as at the Tavistock Clinic, I received increasing attacks in the FMS newsletters and online pressure groups devoted to False Memory Syndrome. Members of Parliament who supported the work were also attacked. As my involvement in the field of ritual abuse and dissociation continued, there were more malicious ad hominem attacks online and in the media. The publication of the book one year after the FMS was created was framed as a memory war at the time. This was linked to the growth of survivor organizations, child protection procedures, allegations of ritual abuse and awareness of DID which emerged into social awareness at the same time.

Whilst Roger Scotford, himself, invited me to meet with him, and he attended several of my talks, and was always courteous (Sinason, 1998), there was an increase in discourtesy from his successors. In the same period, a small number of alleged "recanters" who blamed their "false memories" on therapy were publicized. Respect for professional training and scientific comment plummeted. The 1995 scientific report from the British Psychological Society (Morton, Andrews, Brewin, Davies, \& Mollon, 1995) showing that recovered memory could be accurate was largely ignored in favor of an unofficial report by a small number of False Memory psychiatrists. Professor Sidney Brandon stated unequivocally, against all scientific evidence, that recovered memory was a myth. This is a position the FMS continue to hold. The Brandon report accused therapists of planting memories through questionable techniques and said it was an area which threatened to bring the profession into disrepute, a term which concerned insurance companies and training programs seized on and taught.

There was a new fear of litigation, public exposure of patients, the treatment alliance, concerns about clinical notes being taken by courts, and a fear of considering reality. Psychotherapy was now seen as the perverting agency responsible for the significant increase in survivors coming forward. Professional bodies failed to take this up, not using their theoretical knowledge to understand the societal terror that recognition of widespread abuse had caused. False Memory Societies seized on DID as a further example of recovered memory which must be iatrogenic. As non-clinicians they have the freedom to publicly attack in an ad hominem way. Despite the work of Brand et al. (Brand, Lowenstein \&Spiegel, 2014), Reinders et al. (Reinders et al., 2003, Reinders, Willemsen, Vos, den Boer, \& Nijenhuis, 2012; Reinders et al., 2016), Salter (2017), and many others in the International Society for the Study of Trauma and Dissociation (ISSTD), DID continues to be unscientifically seen as a therapist-created disorder.

\section{The Current Situation}

Psychoanalytic and psychotherapy organizations in the UK have, since 2014, sought to join the voluntary register of the Professional Standards Authority (PSA) in the hope of allaying public fear over psychotherapy standards. 
The PSA allows and encourages third party complaints. This means that an allegedly abusing parent or family member can write to the PSA against the wishes of an adult child, who has capacity, stating that any disclosure of abuse has come from therapy. The historical overprotection of confidentiality has crumbled almost to the opposite position.

Survivor organizations have proliferated and caused the greatest political moves forward in the absence of leadership coming from professional organizations. Memory remains under attack. The narrative presented by the FMS allows any memory of childhood trauma to be dismissed, almost a priori, as a "recovered memory" that must have been created by a "regression therapist." In the case of most of the very traumatized dissociative patients I have worked with and known, they experience a daily struggle with terrible memories that were present long before embarking on any process of psychotherapy. The PSA, who accredit voluntary registers from psychotherapy organizations, until recently saw "False Memory Syndrome" as an agreed scientific term. Indeed, they have accepted the FMS as a stakeholder. The PSA is accountable to Parliament and aims to improve the protection of the public. It invites those who are interested in its aims to become Stakeholders. Perhaps more worryingly, the British Psychological Society itself, despite espousing research which proves recovered memory can be correct, has allowed psychologists who are on the FMS Board to lend their names to non-scientific statements, and professional journals are nervous at scientific papers on the subject (Andrews \& Brewin, 2016).

It is not surprising that the FMS lineup of "bizarre," "fantasist," "deranged" therapists who accept memories of ritual and other abuse, is believed so easily. Their approach is gratefully accepted by parts of society, including some professionals. Reality is always harder to face. Detective Chief Inspector Clive Driscoll, who solved a major UK racist murder case, the Stephen Lawrence case, and the only honor killing case in the UK where the body was not found, said the easiest way to get away with pedophilia in the UK was to put on a cloak and mask, and then no one would believe the child. The moment any form of abuse or any alleged memory of abuse is made to be "impossible," the door has been opened to greater sadistic cruelty.

Despite the scientific dismantling of some of its key tenets internationally, and especially by ISSTD clinicians and researchers (Salter, 2017), the FMS has succeeded in partially damaging the UK treatment climate for survivors and those working with them. Despite the \#metoo movement and the greater social awareness of the extent of abuse, a relatively small number of allegedly innocent parents and their chosen experts have changed the field in the last few decades, aided and abetted by insurance companies, registration bodies and a trauma-resistant public. Memory has become reactively disbelieved rather than curiously explored. 


\section{Personal Learning}

With regard to the nature of traumatic memory in clinical work, I have always been clear. When a traumatized patient asks, "Do you believe me?" I can truthfully reply, "Of course I believe you. You have clearly gone through pain to be like this and you are the evidence. But we may never know exactly what has happened." Psychoanalytic practitioners do not "push" and, far from longing to receive catastrophic narratives, can often take more time than is helpful. The ISSTD Treatment guidelines for DID represent the scientific position that memory of trauma can be recovered and be accurate and that distortions can take place.

I was not surprised when a patient with a severe intellectual disability, who stated she had been abused by former Prime Minister Margaret Thatcher, was able to later show she had been abused whilst the "Spitting Image" puppet show was on television with a puppet Margaret Thatcher speaking. Similarly, my own data showed in $2 \%$ of cases the wrong person could be named. However, embarrassingly, the most significant mistake on memory I made (Sinason, 1998, p. 4) was stating one the FMS or FMSF would still thoroughly agree with. I wrote, "Individuals with severe dissociative disorders are particularly hypnotizable, suggestible, and fantasyprone." This idea has now been disputed by major research papers by Vissia et al. (2016), Reinders et al. (2012) and Brand et al. (2014). Nevertheless, it remains intact with FMS groups.

I also slowly learned to differentiate between the kinds of memories of people with DID. Professor John Morton (Morton \& Sinason, 2014) found from his memory research that there was a difference between those who had subjective amnesia between selves and those who had objectively confirmed amnesia. Whilst amnesia between most states is a given in the field of DID, Professor John Morton was able to show there was a difference in the nature of the amnesia. He found that with some people, whilst they experienced amnesia, there was a leakage of language breaking through, whilst in others there was no leakage of language at all. In other words, there could be an objectively proved amnesia as well as a psychological amnesia. Our hypothesis is that the objectively proved amnesia represents a quaternary structural dissociation which is deliberately created.

Yet, my largest learning has been over what is societally unbearable for us to know. On knowing what one is not supposed to know (Bowlby, 1979) leads to denial, attack, and paradigm shift. Turning perpetrators into monsters rather than wounded individuals who did not access treatment and repeating newspaper headlines that say "this will never happen again" or "monster attacks child," adds to the hiding in plain sight. With inadequate treatment for victim-perpetrators and professional fearfulness, a small but significant group of perpetrators have found a way to hide. I have had to learn that therapists sadly (including myself) are not better at facing reality than other groups. It was, after all, a pediatrician, Kempe, who revealed 
the physical abuse behind the label of "clumsy child" and the growth of the women's movement that paved the way for child abuse to be recognized. It was not psychotherapy. Additionally, having followed my clinical and academic traditions by naming the abuse that was causing the greatest fear to clients I learned that professionals in the field of abuse could be equally fearful over the power of the naming. Why had I used the word "Satanist" and "ritual?" Why had not I stayed with terms like "organized?" At least the FMS was clear there. They have often commented on professionals trying to hide behind names that draw a veil over the religious or pseudo-religious aspects. Coming from the field of intellectual disability where names change every few years (special needs, developmental delay, retardation, handicap) in the hope that the bad thing will go away I find that knowledge is helpful in this field. Fascism plus a deity is always more dangerous than fascism alone as we are finding out only too clearly in the wider world.

In trying to see and name, against societal wishes, we face a harder internal and external professional task. As Milan Kundera (1980) said, "the struggle of man against power is the struggle of memory against forgetting."

\section{REFERENCES}

Ades, R. (Ed.). (2016). The collected works of D. W. Winnicott: Volume 12, appendices and bibliographies. New York, NY: Oxford University Press.

Andrews, B., \& Brewin, C. R. (2017). False memories and free speech: Is scientific debate being suppressed? Applied Cognitive Psychology, 31(1), 45-49. https:/ / doi.org/10.1002/acp.3285

Bowlby, J. (1979). On knowing what you are not supposed to know and feeling what you are not supposed to feel. Canadian Journal of Psychiatry, 24(5), 403-408.

Brand, B. L., Lowenstein, R. J., \& Spiegel, D. (2014). Dispelling myths about dissociative identity disorder treatment; an empirically based approach, Psychiatry, 77(2), 169-189.

Butler-Sloss, E., Great Britain. Department of Social Services. (1988). Report of the inquiry into child abuse in Cleveland 1987, Cm. 412. London, UK: Her Majesty's Stationery Office 0101041225.

Department of Health and Social Security. (1986). Child abuse: working together: A draft guide to arrangements for interagency cooperation for the protection of children. London, UK: Great Britain. Department of Health and Social Security.

Hayman, A. (2003). Epilogue: A psychoanalyst looks at the witness stand. In C. Levin, A. Furlong, \& M. K. O'Neal (Eds), Confidentiality: Ethical perspectives and clinical dilemmas (pp. 293-308). Hillsdale, NJ: Analytic Press.

Hayman, A. (2013) What do our terms mean? Explorations using psychoanalytic theories and concepts (IPA: Controversies in Psychoanalysis). London, UK: Karnac Books.

Kahr, B. (2016). Tea with Winnicott. London, UK: Karnac Books.

Kempe, C. H, Silverman, F. N., Steele, B. F., Droegemueller,W., \& Silver, H. K. (1962). The battered-child syndrome. JAMA, 181(1), 17-24. 
Kundera, M. (1980). The book of laughter and forgetting (M. H. Heimm, Trans.). Harmondsworh, UK: Penguin Books.

McCarthy, B. (1988). Are incest victims hated? Psychoanalytic Psychotherapy, 3(2), 113-120. doi:10.1080/02668738700700101

McHugh, P. R. (2008). Try to remember: Psychiatry's clash over meaning, memory and mind. New York, NY: Dana Press.

Morton, J., Andrews, B., Brewin, C., Davies, G., \& Mollon, P. (1995) Recovered Memories: The report of the working party of the British Psychological Society. Leicester, UK: British Psychological Society.

Morton, J., \& Sinason, V. (2014, October). Quaternary Structural Dissociation. Presented at the Quaternary Structural Dissociation Symposium at the 31st Annual International Society for the Study of Trauma and Dissociation (ISSTD) Conference, Long Beach, CA.

Reinders, A. A. T. S., Nijenhuis, E. R. S., Paans, A. M., Korf, J., Willemsen, A. T. M., \& den Boer, J. A. (2003). One brain, two selves. Neuroimage, 20(4), 2119-2125.

Reinders, A. A. T. S., Willemsen, A. T. M., Vissia, E. M., Vos, H. P. J, den Boer, J. A., \& Nijenhuis, E. R. S. (2016). The psychobiology of authentic and simulated dissociative personality states: The full monty. Journal of Nervous and Mental Disease, 204(6), 445-457. doi:10.1097/NMD.0000000000000522

Reinders, A. A. T. S., Willemsen, A. T. M., Vos, H. P. J., den Boer, J. A., \& Nijenhuis, E. R. S. (2012). Fact or Factitious? A Psychobiological Study of Authentic and Simulated Dissociative Identity States. PLOS ONE, 7(6). https:/ / doi.org/10.1371/journal.pone.0039279

Richardson, S., \& Bacon, H. (2018). Child sexual abuse: Whose problem? Reflections from Cleveland, Revised Edition. Bristol, UK: Policy Press.

Salter, M. (2017, October 2). Attacks on the credibility of abuse survivors are not justified by research. The Guardian, UK.

Simon, B. (1992). "Incest-see under Oedipus Complex": The history of an error in psychoanalysis. Journal of the American Psychoanalytic Association, 40(4), 955-988.

Sinason, V. (1988a). Dolls and bears: From symbolic equation to symbol: The significance of different play material for sexually abused children and others. British Journal of Psychotherapy, 4(4), 349-363.

Sinason, V. (1988b). Richard III, Hephaestus and Echo: Sexuality and mental/ multiple handicap. Journal of Child Psychotherapy, 14(2), 93-105.

Sinason, V. (1988c). Smiling, swallowing, sickening and stupefying: The effect of sexual abuse on the child. Psychoanalytic Psychotherapy, 3(2), 97-111.

Sinason, V. (Ed.) (1994). Treating survivors of Satanist abuse. London, UK: Routledge.

Sinason, V. (Ed.). (1998). Memory in dispute. London, UK: Karnac Books.

Sinason, V. (Ed.). (in press). Trauma and Memory: Whose War? Abingdon-on-Thames, Oxfordshire, UK: Routledge.

Sinason, V., \& Svensson, A. (1994). "Going through the fifth window: Other cases rest on Sundays. This one didn't." In V. Sinason (Ed.), Treating Survivors of Satanist Abuse (pp. 13-22). London, UK: Routledge.

Vissia, E. M., Giesen, M. E., Chalavi, S., Nijenhuis, E. R. S., Draijer, N., Brand, B. L., \& Reinders, A. A. T. S. (2016). Is it trauma- or fantasy-based? Comparing dissociative identity disorder, post-traumatic stress disorder, simulators, and controls. Acta Psychiatrica Scandinavica, 134(2), 111-128. doi:10.1111/acps.12590

Vizard E., Monck, E., \& Misch, P. (1995). Child and adolescent sex abuse perpetrators: A review of the research literature. Journal of Child Psychology and Psychiatry, 36(5), 731-756. 